\title{
ARTICLE
}

\section{Engineers Engaging with Community: Negotiating Cultural Difference on Mine Sites}

\author{
Rita Armstrong ${ }^{*}$ and Caroline Baillie ${ }^{\dagger}$ \\ University of Western Australia, * rita.armstrong@uwa.edu.au, + caroline.baillie@uwa.edu.au
}

In this paper we scrutinize the concepts of culture and cultural relativism and argue that, despite difference in academic interpretations, they have relevance for engineers in their working lives. Engineers, particularly those who work for transnational resource companies, often confront different belief systems when they work on site. This article looks at the misunderstandings that can arise from superficial readings of cultural relativism, as well as the productive relationships that can emerge when engineers engage in a meaningful way with other cultures and epistemologies. This type of engagement has the potential to transform engineering knowledge and practice. We argue that it is important for engineers to understand not just why, but also how, culture matters when negotiating an equitable relationship with the communities in which they work.

KEYWORDS: engineering practice, anthropology, cultural relativism

\section{INTRODUCTION}

Engineering practice inevitably has an impact on peoples' lives in the cultural, social and economic realms regardless of whether that work is carried out within a framework of participatory development or within a framework of economic growth and technological progress. When it comes to designing an engineering system or product, and bringing that project to fruition, engineers will encounter cultural and social diversity. Addressing that diversity may take place within a participatory model-in which engineers ask locals (usually in the Global South) what they want and try to meet those needs-or within a stakeholder model in which people (usually in the Global North) are asked about the potential impact of a development which is deemed necessary for the greater good. Whether engineers are providing innovative solutions to the problems encountered in poor or affluent societies, they are increasingly expected to understand, and resolve, the complicated problems arising from cultural and social diversity that attend any of these projects.

Michel Callon introduced the notion of 'engineer-sociologists' (Bijker et al, 1989) and proposed that engineers who bring about a new technology, whether the designers, the developers or those involved at the implementation stage, actually engage in the kinds of debates that are usually considered to be within the field of sociological or anthropological analysis. Callon illustrated his idea with 'forecasting' for the motorcar industry in France at the beginning of the 1970s about the introduction of an electric car (VEL), yet his ideas have much wider implications. If engineers are to act in some part as anthropologists or sociologists, what knowledge and ways of thinking and acting do they need to be familiar with? What are the basic ideas in a field such as anthropology which might be important for engineers to be aware of? In this paper we consider the most fundamental 
anthropological concept-cultural relativism-and consider how it is played out in the field of engineering practice.

Using examples from the resource economy, it is clear that staff on a mine site encounter cultural difference at many levels. Many workers-from drillers, electricians, welders, and haul truck drivers to engineers for example-are now required to undergo cross-cultural training which is intended to educate them about, and instill respect for, cultural difference. This type of training is based on the concept of cultural relativism, in which all cultures are seen as 'separate yet equal'. At another level, mine managers are required to negotiate an equitable working relationship with Indigenous communities who live on or alongside mine sites. This is a more complicated engagement and requires a shift from a simple acceptance of 'exotic' beliefs to a deeper understanding of the history, politics and internal divisions that have shaped the beliefs of the people on whose land they are working.

In this paper we look at the way popular ideas about diversity and difference are informed by the anthropological concept of cultural relativism and argue that, despite controversy about the utility of the term, it is still a useful conceptual tool with which to understand, and create a dialogue with, other cultural worlds. Nonetheless, as Abu Lughod and many anthropologists have pointed out, a superficial reading of relativism-which assumes cultures are homogenous, that they do not shift and change, and are not internally shaped by class or gender-can have dangerous consequences (Abu Lughod, 2002). Consideration of two narratives of engagement between mine managers and local communities reveal how 'superficial' and 'deep' readings of cultural difference are played out in working life. These stories are contemporary examples of just how slippery the culture concept can be particularly if there is no guide to 'reading' local knowledge. In the first narrative, an anthropologist was employed as a kind of 'cultural broker' between the company and the Lihirian community in Papua New Guinea while in the second narrative, we see engineers acting 'as anthropologists' in order to negotiate an equitable relationship with Aboriginal groups in North Western Australia. These are not narratives of resistance: although set in very different contexts, both local groups wished to engage with mining companies. The shape of that engagement was, however, very different. The main point though is that engineers who work on mine sites cannot ignore culture. To help engineers grapple with this challenge, we argue that interdisciplinary understandings of culture and difference should be embedded within engineering education.

\section{Cultural Relativism in the Academy}

\section{Understanding Difference between Societies: Classical Cultural Relativism}

The concept of cultural relativism, which has been defined as a perspective from which "the beliefs and practices of any society can only be judged by the values and the standards prevalent in that society" (Ingold, 1994, p. 329), is considered a hallmark of anthropological thought. Before considering this idea and the way it impacts on engineering practice, however, we need to have some sense of what anthropologists mean when they speak about 'culture'. This is a vexed topic, about which much has been written, ${ }^{1}$ but we can get some sense of the way in which anthropologists apprehend culture from a series of well-known definitions, the first written in the late nineteenth century and the last one written a hundred years later:

\footnotetext{
${ }^{1}$ Clyde Kluckhohn and Alfred Kroeber famously came up with 161 definitions of 'culture' in 1952.
} 
(that) complex whole which includes knowledge, belief, art, law, morals, custom and any other capabilities and habits acquired by man as a member of society. (Tyler, 1871)

an historically transmitted pattern of meanings, embodied in symbols, a system of inherited conceptions expressed in symbolic form by means of which (humans) communicate, perpetuate and develop their knowledge about and attitudes towards life. (Geertz, 1973, p. 3)

Culture is the learned, socially acquired traditions and lifestyles of the members of a society, including their patterned repetitive ways of thinking and feeling. (Harris, 1983, p. 5)

These three definitions, from iconic figures in anthropological thought, convey the sense of 'culture' as a system of shared meanings which can be expressed in a variety of ways from symbols, behaviour, language and text to material culture: "culture mediates and conditions all knowledge of the world, like a lens" (Erikson \& Murphy, 2003, p. 163). Much of the debate about cultural systems is not about these inherent qualities but about the ways in which they are represented, and we will return to these a little later.

Teaching cultural difference often starts with the well-known (yet still powerful) quote that "each man calls barbarism what is not his own practice for indeed it seems we have no other test of truth and reason than the example and pattern of the opinions and customs of the country we live in" (1957, p. 152). It comes from Michel de Montaigne, a French essayist from the late sixteenth century, when he wrote a piece describing European reactions to the behaviour of 'savages' in the New World. It is cited extensively in histories of social thought to illustrate that cultural relativism-refusing to compare or evaluating the cultures of various societies according to one's own-is not a new idea. These views only took coherent and popular shape at the end of the nineteenth century, largely due to the desire to counteract the prevailing racism of the nineteenth century in which societies and cultures were situated on a linear progression from savagery to civilization, and of the twentieth century in which the same thinking was used to justify acts of genocide and apartheid. Franz Boas, considered the founder of American anthropology, is generally seen as a man whose entire career was dedicated to demonstrating the racial, linguistic and cultural equality of all peoples (e.g. Hyatt 1990, Lewis 2001). "Even if it was not explicitly theorized, Boas' antievolutionism had a strongly anti-racist cast; Boas fought against the disparagement of primitive peoples, of ethnic immigrants, and of blacks in the United States by valorising their customs and showing these to be at least as sophisticated and as intricate as our own" (Knaupft, 1996, p. 21).

The main features of this early relativism was that cultures were 'separate but equal', that is they constituted separate worlds based on a unique cultural logic and the key to understanding that logic lay in the emerging ethnographic method. The importance of understanding the insider's-or emic-perspective was, at that time, advocated by ethnographers such as Malinowski $(1922,1935)$ and Evans-Pritchard. Evans-Pritchard's work, Witchcraft, Oracles and Magic among the Azande (1965), is a classic ethnography which is often used as primary learning text to introduce students to the relativism of logic and rationality. In his description of witchcraft as an epistemological system with which the Azande made sense of the world-in the explanation of misfortune and other events for example-he challenged European notions that scientific explanations were 'natural'. It was specious, he claimed, to consign beliefs in witchcraft into a 'mystical', and therefore ridiculous, category. 
But it may not at all times have that sense for primitive man. For instance, many peoples are convinced that deaths are caused by witchcraft. To speak of witchcraft being for these people a supernatural agency hardly reflects their own view of the matter, since from their point of view, nothing could be more natural. (EvansPritchard, 1965, p. 109)

Claude Levi-Strauss, French anthropologist and philosopher, also criticized the set of assumptions which inspired Western thinkers to make the distinction between scientific thought and nonscientific thought (which included the supposedly illogical knowledge systems of indigenous or small-scale societies and the supposedly irrationality of most religious beliefs). What makes LeviStrauss' approach different from other anthropologists-such as Boas or Evans-Pritchard-is that he did "not limit himself to an attack on the evolutionary and world historical paradigms" (Pace 1983, p. 126) but criticized the whole set of assumptions on which the concept of the 'primitive' was based. He wanted to construct a model of difference based on the principles of a deeper, cognitive equality. People everywhere, he argued, had a need for intellectual order and he used material on kinship, myth and social organization to demonstrate that these knowledge systems required the same kind of intellectual effort as that required to produce scientific theories. He used, for example, complex Indigenous classificatory systems in both kinship and ethnobotany to demonstrate that literacy was not a pre-requisite for either complex intellectual endeavour or for the ability to solve complex problems.

This, then, is an encapsulation of how university students are taught that culture 'matters' and academics stress that the notion of cultural relativism had its beginnings in the need to demonstrate the equality of cultures in the face of dominant ideologies within Europe and North America which were informed by implicit beliefs in the value of modernity and progress, and underpinned by racism. The desire to find 'evidence' of rationality and logic in small-scale societies was forged by the need to refute the prevailing idea that scientific reasoning was the result of an evolving rationality which found its fullest expression in western societies.

It is from these historical beginnings that the classic notion of relativism emerged; the basic assumption that cultures and belief systems with their own internal logic cannot be hierarchically situated is now considered central to anthropological understanding. It is this classic definition which has found its way into public life. The idea that we must respect difference, and not valorise our own culture above others, is now a ubiquitous concept, used in many settings from primary school assemblies (where children acknowledge difference and respect for others in multicultural settings) and in corporations (where employees undergo 'cross-cultural training' sessions where they are taught to be sensitive to, and respect, the beliefs and behaviours of others). Cultural relativism, in popular usage, is usually translated as a need to acknowledge and accommodate diversity in a humanist framework. Relativism is usually understood in this discourse as a 'need for cultural sensitivity' on the part of dominant (usually white) societies towards the beliefs and practices of other-say Indigenous or Muslim-societies. But the challenge of acknowledging cultural diversity goes far deeper than demonstrating that the

seemingly strange or irrational makes sense when placed in its proper context ... [I]t strikes at the heart of some of the most basic presuppositions of Western thought itself. To take this knowledge seriously, and be the wiser for it, means bringing it to bear in critical engagement with these presuppositions. In this engagement, every single one of the key concepts of Western civilization-concepts like society, culture, nature, language, technology, individuality and personhood, equality and 
inequality, even humanity itself-becomes essentially contestable. (Ingold, 1994, p.

ix)

\title{
Understanding Cultural Difference within Societies: Surface and Deep Readings
}

The way in which cultural diversity is represented and understood has changed considerably within the anthropological discipline since the 1930s and 1940s. From the 1950s onwards anthropologists began to pay attention to culture as a system that can embody the values of everyday life as well as ideologies that can empower some and subordinate others. Knowledge systems are not equally shared; these can be distributed or controlled according to one's age or gender (Keesing, 1987). Furthermore, cultures change; historical changes in population movements, technologies and subsistence all affect the way we view the world and each other. Even Lila Abu-Lughod, a stringent critic of Western anthropological practice, acknowledges that the most important of culture's advantages is that it removes difference from the realm of the natural and the innate (1991). However it is conceived, culture is learned and can change. But despite its antiessentialist intent, she maintains, the culture concept retains some of the tendencies to freeze difference. Appadurai has also underlined the complicity of the anthropological concept of culture in a continuing incarceration of "non-western" peoples in time and place (1988). It is largely due to internal critiques such as these that culture is now perceived as contested, historically contingent and socially situated.

As the concept of culture has changed-with the global movement of capital, people and information-so too has the concept of cultural relativism. The classical definition of the term has come under scrutiny and debate for the last sixty years particularly in the field of moral relativism and human rights. The contours of that debate have been summarized by Brown (2008):

\begin{abstract}
Classical cultural relativism, an all-encompassing doctrine that embraces methodological, cognitive, and ethical components, has been debated by scholars for more than a half-century. Today's consensus is that, as originally conceived, cultural relativism has significant flaws. It tends to exaggerate the internal coherence of individual cultures. It overstates differences between societies and underestimates the possibility of transcending these differences. Its totalizing qualities invite moral minimalism and foster hostility to comparative analysis. (p. 371)
\end{abstract}

Nevertheless, he and others have concluded that cultural relativism is a set of ideas worth keeping in the interests of cross-cultural understanding and mitigating against that human propensity to 'call barbarism' what is not their own practice (Geertz, 1984). To be a relativist is not to claim that social worlds are incommensurable (Brown, 2008, p. 372) but to assert the opposite: it is only in understanding that difference that dialogue becomes possible.

\section{DeALING WITH DifFERENCE IN THE WORKING WORLD}

With the increasing recognition of Indigenous human rights, and the institutionalization of impact assessment for large-scale mining operations, local communities are now incorporated as key 'stakeholders' in the resource economy (O'Faircheallaigh, 1999). The use of a 'stakeholder' model does not, as Ballard and Banks (2003) point out, capture the complexity of relationships that form around a mine site. The quality of these relationships is affected by a range of issues, for example: the extent to which communities on or within the mine site have been previously marginalised, the political stability of government, the importance of 'community engagement' within the corporate culture of individual firms, and the existence of land rights. 
The following narratives reveal two very different encounters between mining companies and local communities: in Papua New Guinea, local men manipulated ideologies about gender to prevent women from working on the mine site and presented these ideologies to (male) mine managers as timeless and immutable; in the second we see how it took twenty years for Aboriginal men and women to negotiate equitable relations with the mining company within a framework of local knowledge.

\section{(Mis) Understanding of Local Knowledge on a Mine Site in Papua New Guinea}

Many mining companies make the effort to understand local culture and to engage with local communities about the impact of their activities by employing anthropologists as consultants or 'cultural brokers'. Martha Macintyre is one such anthropologist who chose to work as a consultant for gold mines at Misima and Lihir in Papua New Guinea. She says that by putting her knowledge to some useful end she could "pay a debt" to the people of Milne Bay who had shared their knowledge and understanding with her over the years. Macintyre was also aware of the impact of development on women's lives and wanted to use her knowledge and contacts to mitigate that impact as much as possible. What follows is an abbreviated account of Macintyre's experiences (2001).

At Lihir, the women expressed a great deal of interest in earning money on the mine site. "Not having been exposed to some of the stereotypes of gender and modern work, in interviews they expressed enthusiasm for training in driving vehicles or operating machinery and learning various trade skills" (2001, p. 110). This initial enthusiasm evaporated when they saw very few women working on the mine site, either expatriates or locals, and only a handful persevered with the driver-training scheme. This small handful of women was supported by the European senior male managers and a female expatriate was employed to teach them how to drive heavy vehicles. But "Lihirian men objected to women driving vehicles because they considered it men's work and they wanted all driving jobs" (2001, p. 110). The reaction of the Lihirian men, Macintyre says, was both inventive and ingenious.

The men explained to mine managers that local ideas about gender and pollution, particularly menstrual pollution, would mean that men would be unable to use machines which Lihirian women had been using. Menstrual blood is considered polluting amongst many New Guinea societies, particularly in the highlands. The men argued that not only would menstruating women pollute the vehicle, but that their polluting powers (even when they were not menstruating) would emanate from their bodies and permeate the fluids in the engine. "The heat and sweat from a woman driver would infuse the oil circulating in the machine and thus make the engine dysfunctional when men used the vehicle. Finally they produced their 'trump card': the sump, as the repository of machine and female waste products would be filled with hazardous waste that would endanger the lives of the mechanics who had to dispose of it when they serviced the vehicles" (2001, p. 111). As Macintyre observes, "the men were aware that an appeal to 'kastom' always seemed to impress outsiders" (2001, p. 111). Only a few women were prepared go against these arguments in order to pursue a driving job.

Local ideas about gender relations and female pollution also impacted on the design of workers' houses, although in a very different way. Local men initially felt that if houses were built on stilts, women would very likely walk around inside the house while men were sitting underneath, and this was seen as disrespectful as well a breach of pollution rules. Their desire, however, to live in houses that resembled those of senior public servants in the provincial capital, outweighed customary beliefs and they eventually 'insisted' on raised houses. 
By deferring to local 'customs' regarding female pollution, the expatriate mining community at Lihir would have felt they were engaging with the community in a positive way and, more importantly, in ways that avoided the kind of conflict that erupted on other mines in Papua New Guinea. Their surface reading of different beliefs and values aligns with the classic concept of relativism in which one should accept 'exotic' beliefs as different but understandable. Without a fine grained understanding of local knowledge-that culture is gendered or that cultural beliefs are not immutable or fixed-mining companies are likely to make an impact on local societies in ways they never imagined. Furthermore, as Macintyre has pointed out, it is rare for engineers to be employed as 'liaison officers', so that meaningful understanding of local culture and politics is relegated to a person with 'soft' skills (pers. comm.) such as the anthropologist or community liaison officer. The information which a mine manager may receive is therefore second- or third-hand, and it is left to chance whether a particular manager has the life experience, inclination, or skill to see a particular kastom as an ideological sleight of hand or a popularly held belief.

\section{Engagement with Local Knowledge on a Mine Site in North-West Australia}

The Kimberley region is situated in the far north of Western Australia. Diamonds were first discovered in the East Kimberley in 1979 in an area known as the Barramundi Gap which is of special significance to Aboriginal women "because it is one of the numerous resting places of the female Barramundi creative Dreaming being" (Doohan, 2008, p. 17). ${ }^{2}$ The mining company, CRA (Conzinc Rio Tinto), signed a Good Neighbour Agreement with the local Aboriginal communities in 1980 which allowed them access to the site in return for a 'range of benefits'. It took over 20 years for the company to reach an understanding with the Aboriginal groups about what these 'benefits' might entail, and what kind of relationship would be formed with the miners at Argyle. The history of that relationship has been detailed in Kim Doohan's account, Making Things Come Good: Relations between Aborigines and Miners at Argyle (2008). What is striking about this account is the length of time it has taken for miners and Aboriginal people to accommodate each other's knowledge systems and worldviews and to resolve that accommodation within their working relationship.

There was little room for negotiation when the Agreement was first signed in the 1980s; at that time senior personnel were less interested in cross cultural understanding, and more intent on getting access to diamond deposits in return for helping specific groups achieve economic independence by cash handouts. While the Aboriginal communities were eager to achieve independence from government 'hand outs' via mining money, relationships with the mining company were framed by local understandings of reciprocity which encompassed a wider, and much more enduring, notion of obligation which extended to other Aboriginal groups beyond the mine site. Aboriginal people felt their notions of reciprocity were "poorly understood by mine personnel" (Doohan, 2008, p. 94). They acknowledged it was not possible to stop the mine's progress and would rather "make things come good" by getting mine personnel to understand how Aboriginal people think and feel about social relationships and the environment (Doohan, 2008, p. 94).

\footnotetext{
2 For the miners, diamonds exist because of ancient geological formations, while their discovery "reflected the triumph of science, technology and economics" (Doohan, 2008, p. 21). This notion of 'discovery' is quite different than the local view; it was well known to female elders with knowledge of the Barrumundi dreaming being that the diamonds had always been there. According to Aboriginal tradition, when the Barramundi escaped from a trap set by the local women, she left some of her scales behind; her escape route is evidenced by the gap in the ranges where the mine is located. The pink diamonds are believed to be her transformed body fat, while the brown and yellow diamonds are internal organs (Doohan, 2008, pp. 20-21).
} 
There was mutual agreement to form a Cultural Group in 1993 in which senior Kija men and women taught the miners about Kija laws and customs, contact history and social organisation (Doohan, 2008, p. 104). The fact that all miners had to experience cross-cultural training was seen by Aboriginal people as a sign that Argyle was finally coming to understand 'blackfella' ways. But it was the threatened mine closure in 1996 which was the catalyst that inspired the Aboriginal women to perform specific ceremonies on the mine site-initially to prolong the life of the mine and later to ensure the safety of the workers-which involved all mine personnel. This 'performative cultural practice', Doohan claims, worked on the miners in a powerful and compelling way (2008, p. 109). A brief review of these events will illustrate the significance of these rituals, both for the mine workers and management personnel, and for the Aboriginal community.

When it was decided that the life of the open pit mine was coming to an end, a major review of extracting processes, management practices and financial matters took place (Doohan, 2008, p. 111). In summary, Argyle "knew there were still some diamonds in the bottom of the open pit, but that it was becoming too dangerous to mine them". The mine manager, a civil engineer, realised that walls of the pit were likely to collapse under existing conditions and forestalled this by stabilising the rock surface of the open pit walls with rock bolts, mesh, concrete and other materials (Doohan, 2008, p. 111). With these innovations, the life of the open pit mine was extended till 2008. Mining personnel then began looking at ways of extracting more diamonds via underground mining. Funds were secured from Rio Tinto to construct an underground exploratory tunnel in 2003 and the feasibility study determined that enough diamonds could be extracted to justify further expenditure-according to safety conditions-until 2018.

When it was decided there were enough diamonds to continue underground mining, the women began to perform ceremonies on site-known as manthe - that welcomed miners and kept them safe. Routine participation of all new mine workers, from drivers to managers, was expected from 2003 onwards. Participating in these rituals, which embodies the meaning of different cultural systems, has had an impact on mine workers. Doohan notes that the reactions amongst miners who have participated in the manthe ceremony range from mild curiosity to being "genuinely moved and even changed by the experience" (Doohan, 2008, p. 120).

Just as there are different explanations given for the existence and location of diamonds in the Barramundi Gap, there are different explanations given for the Argyle mine's continuing productivity. According to the engineers, the mine continued to operate because of their determination to "tackle difficult engineering problems" and further geological analysis which led to a feasibility test of underground mining (Doohan, 2008, p. 135). Senior Aboriginal men and women have very different explanations. "According to them, it was their talking to the Barramundi and calming of the spirits of the 'old people' that ensured the continued presence of diamonds and thus of the mine. They achieved this by conducting (rituals) to ask the Barramundi to reveal more of herself, and by their continued engagements and conversations with the Barramundi during the mine's recent history, since 1996" (Doohan, 2006, p. 135). The Kija men and women in particular feel they have reassured her and made her more tolerant of the miners' activities and more willing to "give up more of herself, namely the diamonds" (Doohan, 2008, p. 135).

The Aboriginal people who enact the manthe ceremony at the Argyle mine clearly believe that participation in these ceremonies is a way forward for meaningful engagement with miners although they are clearly concerned that many miners don't "really understand" the significance of what they are doing. Nonetheless they believe it is important for miners to understand their history and worldview if relations are going to work in a sustainable way. The approach of these Aboriginal elders also illustrates how dangerous it can be to dichotomize the difference between 'traditional' 
and 'modern'; the Kija are not against working on mine sites, or receiving money from mining companies, but they wish to position their relations with miners within their own cultural values.

\section{WAYS FORWARD}

In writing about development, Amartya Sen has argued that economists neglect the concept of culture at their peril. He says that:

The economists' scepticism about the role of culture may ... be indirectly reflected in the outlooks and approaches of institutions like the World Bank. No matter how serious this neglect is (and here assessments can differ), the cultural dimension of development requires closer scrutiny in development analysis. It is important to investigate the different ways-and they can be very diverse-in which culture should be taken into account in examining the challenges of development, and in assessing the demands of sound economic strategies. The issue is not whether culture matters, to consider the title of an important and highly successful book jointly edited by Lawrence Harrison and Samuel Huntington. That it must be, given the pervasive influence of culture in human life. The real issue, rather, is how-not whether-culture matters. (Sen, 2004, pp. 37-8)

Unlike economists, engineers who work on mine sites cannot ignore culture. But to understand 'culture in action', we need to grasp that culture is fundamentally relational, that it is "not a set of primordial phenomena permanently embedded within national or religious or other groups, but rather a set of contested attributes, constantly in flux, shaping and being shaped by social and economic aspects of human interaction (Rao \& Walton, 2004, p. 4). This is an apparently simple concept-we teach it constantly to university students-but the narratives presented here demonstrate the difficulties of using the concept out in the working world.

Engineers, such as those working at Lihir, may not have known a great deal about local gender relations and the construction of masculinity (how could they?) but one way forward is to be alert to the complexity of the culture concept, to 'know what they don't know' to put it more bluntly. Grasping the nuances of local politics, gender relations and community aspirations is the only way forward in understanding 'how' culture matters. However-and this is one message of the second narrative-those nuances cannot be grasped immediately; it is a lengthy process to create a dialogue between mining companies and the communities who live alongside the mine site. The narratives which we have considered give some sense of the difficulties of apprehending cultural difference, albeit in very different settings.

Twenty years ago, Callon observed that the dialogue between the humanities and the sciences about the impact of technology on society was hampered by defensiveness; he attributed much of this defensiveness to the academic isolation of sociological theory (Callon, p. 98). Much has changed since then. Not only is anthropology a far less homogenous discipline, it also is far more engaged with the impact of mining on both Indigenous and non-Indigenous communities. This engagement itself, however, is far from being unproblematic. Anthropologists have tended to view mining companies as stereotypically menacing and with little regard for Indigenous communities, and some see their discipline as the only one with the conceptual and methodological tools that can 'really' understand local cultures. Local communities may enjoy close relations with anthropologists (such as Martha Macintyre on Lihir) but other Indigenous groups (particularly in Aboriginal Australia) may view them with distrust because of anthropology's historical association with colonisation. As Ballard and Banks point out "the positioning of anthropologists within these 
'resource wars' is far from simple, and a parallel war of sorts is being waged within the discipline about the nature and scope of appropriate forms of engagement" (2003, p. 289).

The complex relationship which develops between the state, miners and Indigenous communities, therefore, requires a level of understanding which is not grasped by many graduates-both engineers and anthropologists. This is being recognised by mining companies that are requesting that all personnel involved in community engagement, whether engineers or anthropologists, get better training before graduation. As Bruce Harvey, Global Leader of Communities for Rio Tinto, states:

The real constraint on improving performance is not a lack of will or failing to embrace the right techniques, but rather a lack of good hands-on people. Currently, neither industry, universities nor other agencies can assure a reliable supply of knowledgeable, competent community professionals. (Harvey, 2005, p.13)

It is clearly important, therefore, to develop engineers' understandings of culture (both their own and others) before they begin their working lives. Embedding post-colonial anthropological 'ways of understanding'-which include a critical attention to culture, power and difference-within engineering education would provide opportunities to question, challenge, and reconstruct engineering knowledge. It would offer transformative possibilities for the ways in which engineers view their own practice and its impact on others. ${ }^{3}$ It would also redress the unease which many anthropologists feel when they see mining companies uncritically deploy 'ethnographic' concepts to facilitate a dialogue which ultimately serves the interests of dominant ideologies about work, profitability and development.

We have attempted, in this article, to demonstrate that 'understanding difference' involves more than a simple acknowledgement of diversity. It requires an acknowledgment of the historical experience of, and cultural diversity within, 'other' societies, and it also requires a self-reflexive understanding that 'our' explanatory paradigms are not universally shared. A critical engagement between anthropology and engineering can take place, we argue, not just at the end point of social impact but also at the birthplace of engineering practice, within the engineering classroom. Sharing narratives about the difficulties and dilemmas faced by engineers on mine sites demonstrates that a nuanced understanding of culture and the differences within and between societies will lead to a better-informed engineering practice.

\section{ACKNOWLEDGEMENTS}

This article was made possible by support from the Australian Learning and Teaching Council Grant, "Engineering Education for Social and Environmental Justice".

\section{REFERENCES}

Abu-Lughod, L. (1991). Writing Against Culture. In Rox, R. (Ed.), Recapturing Anthropology: Working in the Present, (pp. 137-162). Santa Fe: Santa Fe School of American Research Press.

\footnotetext{
${ }^{3}$ Baillie is Principal Investigator on a project funded by the Australian Teaching and Learning Council entitled "Engineering Education for Social and Environmental Justice". This project is looking at ways of embedding an interdisciplinary approach within the undergraduate engineering curriculum at the University of Western Australia so that students are able to critically understand the social and cultural impact of engineering practice.
} 
Abu-Lughod, L. (2002). Do Muslim Women Really Need Saving? Anthropological Reflections on Cultural Relativism and its Others. American Anthropologist, 104(3), 783-790.

Appadurai, A. (1988). Putting hierarchy in its place. Cultural Anthropology, 3, 36-40.

Altman, J. (2009). Contestations over development. In J. Altman \& D. Martin (Eds), Power, Culture, Economy: Indigenous Australians and Mining, (pp.1-16). Canberra: Centre for Aboriginal Economic Policy Research, ANU.

Ballard, C. \& Banks, G. (2003). Resource Wars: the Anthropology of Mining. Annual Review of Anthropology, 32,287-313.

Boas, F. (1911). The Mind of Primitive Man. London: Macmillan.

Callon, M. ( 1989). Society in the Making: The Study of Technology as a Tool for Sociological Analysis. In W. Bijker, T. P. Hughes, \& T. J. Pinch (Eds.), The Social Construction of Technological Systems: New Directions in the Sociology and History of Technology, (pp.83-103). London: MIT Press. First published 1987.

Doohan, K. (2008). Making Things Come Good: Relations between Aborigines and Miners at Argyle. Broome, WA: Backroom Press.

Engineers Without Borders (EWB). (2011). Retrieved on 15 January 2011 from http://www.ewb.org.au/explore/initiatives/ewbchallenge/learningobjectives/learningoutcomes

Erikson, P. A \& Murphy, D. L. (Eds). (2003). A History of Anthropological Thought. Ontario: Broadview Press.

Evans-Pritchard, E. (1937). Witchcraft, Oracles and Magic among the Azande. Oxford: Clarendon Press.

Geertz, C. (1973). Thick Description: Toward an Interpretive Theory of Culture. In The Interpretation of Cultures: Selected Essays by Clifford Geertz, (pp. 3-30). New York: Basic Books.

Geertz, C. (1984). Anti Anti-Relativism. American Anthropologist, 86(2), 263-278.

Harris, M. (1983). Cultural Anthropology. New York: Harper \& Row.

Harvey, B. (2005). Emerging models of community engagement in the Australian minerals industry. Presented at the UN Conference on Engaging Communities in Brisbane, Australia, August 2005. Retrieved from http://www.riotinto.com/documents/MediaSpeeches/UN Conference on Community Engagement BH 150805.pdf

Hyatt, M. (1990). Franz Boas, social activist: the dynamics of ethnicity. New York: Greenwood Press.

Hollis, M. \& Lukes, S. (Eds.). (1983). Rationality and Relativism. Oxford: Basil Blackwell.

Ingold, T. (Ed.). (1994). Companion Encyclopaedia of Anthropology: Humanity, Culture and Social Life. London: Routledge.

Keesing, R. (1987). Anthropology as Interpretive Quest. Current Anthropology, 28(2), 61-176.

Kluckholn, C. \& Kroeber, A. (1952). Culture: A Critical Review of Concepts and Definitions. Cambridge: Harvard University Press.

Knaupft, B. (1996). Genealogies for the Present in Cultural Anthropology. New York: Routledge.

Levi-Strauss, C. (1966). The Savage Mind, London: Weidenfeld \& Nicholson. Original La Pensee Sauvage, 1962, Paris: Plon.

Lewis, H. S. (2001). The Passion of Franz Boas. American Anthropologist, 103(2), 447-467.

Macintyre, M. (2001). Taking Care of Culture: Consultancy, Anthropology and Gender Issues. Social Analysis, 45, 108-120.

Malinowski, B. (1922). Argonauts of the Western Pacific. London: Routledge \& Keegan Paul.

Malinowski. B. (1935). Coral Gardens and their Magic. London: Allen \& Unwin.

De Montaigne, M. (1957). The Complete Essays. Translated and edited by D. Frame. Stanford: Stanford University Press.

O’Faircheallaigh C. (1999). Making social impact assessment count: a negotiation-based approach for indigenous peoples. Society and Natural Resources, 12, 63-80.

Pace, D. (1983). Claude Levi-Strauss: the Bearer of Ashes. London: Ark Paperbacks.

Rao, V. \& Walton, M. (2004). Culture and Public Action: Relationality, Equality of Agency and Development. In V. Rao \& M.Walton (Eds.), Culture and Public Action, (pp. 4-36). Stanford: Stanford University Press.

Sen, A. How does culture matter? In V. Rao \& M. Walton (Eds.), Culture and Public Action, (pp. 37-58). Stanford: Stanford University Press.

Taylor, R. \& Scambury, B. (2005). Indigenous people and the Pilbara mining boom a baseline for regional participation. CAEPR Research Monograph No. 25. Canberra: Centre for Aboriginal Economic Policy Research, ANU.

Tyler, E. B. (1871). Primitive Culture. London: J. Murray. 